\title{
Assessment of heavy metal pollution in surface water
}

\author{
${ }^{1}$ D. Kar; ${ }^{1}$ P. Sur; ${ }^{1}$ S. K. Mandal; ${ }^{2}$ T. Saha $;{ }^{2}{ }^{*}$. K. Kole \\ ${ }^{1}$ Department of Agricultural Chemistry and Soil Science Faculty of Agriculture, Bidhan Chandra Krishi \\ Viswavidyalaya, Kalyani-741235, West Bengal, India \\ ${ }^{2}$ Department of Agricultural Chemicals, Faculty of Agriculture, Bidhan Chandra Krishi Viswavidyalaya, Kalyani- \\ 741235, West Bengal, India
}

Received 15 January 2007; $\quad$ revised 20 May 2007; accepted 9 October 2007; $\quad$ available online 26 December 2007

\begin{abstract}
A total of 96 surface water samples collected from river Ganga in West Bengal during 2004-05 was analyzed for $\mathrm{pH}, \mathrm{EC}, \mathrm{Fe}, \mathrm{Mn}, \mathrm{Zn}, \mathrm{Cu}, \mathrm{Cd}, \mathrm{Cr}, \mathrm{Pb}$ and $\mathrm{Ni}$. The $\mathrm{pH}$ was found in the alkaline range (7.21-8.32), while conductance was obtained in the range of $0.225-0.615 \mathrm{mmhos} / \mathrm{cm}$. Fe, Mn, $\mathrm{Zn}, \mathrm{Ni}, \mathrm{Cr}$ and $\mathrm{Pb}$ were detected in more than $92 \%$ of the samples in the range of $0.025-5.49,0.025-2.72,0.012-0.370,0.012-0.375,0.001-0.044$ and $0.001-$ $0.250 \mathrm{mg} / \mathrm{L}$, respectively, whereas $\mathrm{Cd}$ and $\mathrm{Cu}$ were detected only in 20 and 36 samples (0.001-0.003 and 0.003-0.032 $\mathrm{mg} / \mathrm{L}$ ). Overall seasonal variation was significant for Fe, Mn, Cd and Cr. The maximum mean concentration of Fe (1.520 $\mathrm{mg} / \mathrm{L})$ was observed in summer, Mn $(0.423 \mathrm{mg} / \mathrm{L})$ in monsoon but Cd $(0.003 \mathrm{mg} / \mathrm{L})$ and $\mathrm{Cr}(0.020 \mathrm{mg} / \mathrm{L})$ exhibited their maximum during the winter season. Fe, $\mathrm{Mn}$ and $\mathrm{Cd}$ concentration also varied with the change of sampling locations. The highest mean concentrations (mg/L) of Fe (1.485), Zn (0.085) and $\mathrm{Cu}(0.006)$ were observed at Palta, those for Mn (0.420) and $\mathrm{Ni}(0.054)$ at Berhampore, whereas the maximum of $\mathrm{Pb}(0.024 \mathrm{mg} / \mathrm{L})$ and $\mathrm{Cr}(0.018 \mathrm{mg} / \mathrm{L})$ was obtained at the downstream station, Uluberia. All in all, the dominance of various heavy metals in the surface water of the river Ganga followed the sequence: $\mathrm{Fe}>\mathrm{Mn}>\mathrm{Ni}>\mathrm{Cr}>\mathrm{Pb}>\mathrm{Zn}>\mathrm{Cu}>\mathrm{Cd}$. A significant positive correlation was exhibited for conductivity with $\mathrm{Cd}$ and $\mathrm{Cr}$ of water but Mn exhibited a negative correlation with conductivity.
\end{abstract}

Key words: River Ganga, spatial and temporal changes, heavy metal, water quality

\section{INTRODUCTION}

Ganga, the most sacred and important river of India, is regarded as the cradle of Indian civilization. About $2506 \mathrm{~km}$ of the river stream gives life to twenty-nine cities, seven towns and thousands of villages which are contaminating the river by over 1.3 billion $\mathrm{L}$ waste water per day (Khan, et al., 1998). Among the inorganic contaminants of the river water, heavy metals are getting importance for their non-degradable nature and often accumulate through tropic level causing a deleterious biological effect (Jain, 1978). Anthropogenic activities like mining, ultimate disposal of treated and untreated waste effluents containing toxic metals as well as metal chelates (Amman, et al., 2002) from different industries, e.g. tannery, steel plants, battery industries, thermal power plants etc. and also the indiscriminate use of heavy metal containing fertilizers and pesticides in agriculture resulted in deterioration of water quality rendering serious environmental problems posing threat on human

*Corresponding Author Email: dipankarkar@gmail.com Tel./Fax: +913325809767 beings (Lantzy and Mackenzie, 1979; Nriagu, 1979; Ross, 1994) and sustaining aquatic biodiversity (Ghosh and Vass, 1997; Das, et al., 1997). Though some of the metals like $\mathrm{Cu}, \mathrm{Fe}, \mathrm{Mn}, \mathrm{Ni}$ and $\mathrm{Zn}$ are essential as micronutrients for life processes in plants and microorganisms, while many other metals like Cd, Cr and $\mathrm{Pb}$ have no known physiological activity, but they are proved detrimental beyond a certain limit (Marschner, 1995; Bruins, et al., 2000), which is very much narrow for some elements like Cd $(0.01 \mathrm{mg} / \mathrm{L}), \mathrm{Pb}$ $(0.10 \mathrm{mg} / \mathrm{L})(\mathrm{ISI}, 1982)$ and $\mathrm{Cu}(0.050 \mathrm{mg} / \mathrm{L})$. The deadlier diseases like edema of eyelids, tumor, congestion of nasal mucous membranes and pharynx, stuffiness of the head and gastrointestinal, muscular, reproductive, neurological and genetic malfunctions caused by some of these heavy metals have been documented (Johnson, 1998; Tsuji and Karagatzides, 2001; Abbasi, et al., 1998). Therefore, monitoring these metals is important for safety assessment of the environment and human health in particular. Regrading this background, this survey monitored the surface water 
in the Bhagirathi-Hooghly stretch of the river Ganga in west Bengal, India, considering the spatial and temporal variations in heavy metal content and also to evaluate the status of the river water quality with respect to drinking and agricultural irrigation purposes.

\section{MATERIALS AND METHODS}

Water samples were collected once in every month during April 2004 to March 2005 from two sites (middle of the river stretch and a discharge point) at four monitoring stations viz. Berhampore (BH), Palta (PA), Dakshineswar (DK) and Uluberia (UL) on the river Ganga, a 300 km stretch known as Bhagirathi-Hooghly in West Bengal, India (Fig .1). The samples were collected from a depth of $1 \mathrm{ft}$ below the surface using Nansen type water sampler and kept in polythene containers $(500 \mathrm{~mL})$ with the addition of $2 \mathrm{~mL}$ concentrated $\mathrm{HNO}_{3}$ at $2 \mathrm{~mL}$ in order to preserve the metals and also to avoid precipitation. The $\mathrm{pH}$ of water samples was determined using $\mathrm{pH}$-meter with electronic glass electrode (LI 127 of Elico, India) and conductivity was measured by conductivity-meter (Systronics 304). For the analysis of total heavy metals (dissolved and suspended), water (200 mL) samples were digested with $5 \mathrm{~mL}$ of di-acid mixture $\left(\mathrm{HNO}_{3}: \mathrm{HClO}_{4}:: 9: 4\right.$ ratio) on a hot plate and filtered by Whatman No. 42 filter paper and made up the volume to $50 \mathrm{~mL}$ by double distilled water for analysis of eight heavy metals viz. Fe, $\mathrm{Cu}$, $\mathrm{Mn}, \mathrm{Zn}, \mathrm{Pb}, \mathrm{Cd}, \mathrm{Cr}$ and $\mathrm{Ni}$ using atomic absorption spectrophotometer (GBC-902, Australia) (APHA, 1995). The obtained data were subject to statistical analysis to test the analysis of variance (ANOVA) and correlation among all the parameters using SPSS statistical package.

\section{RESULTS AND DISCUSSION}

The river water samples exhibited an alkaline $\mathrm{pH}$ in the range of 7.21 to 8.32 with an overall mean of 7.80 . Seasonal mean values of $\mathrm{pH}$ varied from 7.7 in monsoon to 7.9 during summer and winter (Table 1). The lowest $\mathrm{pH}$ value was always observed in monsoon at all the four locations which may be due to the dilution effect of rain water (John, 1991). No significant difference was noted in the observed $\mathrm{pH}$ during the summer and winter and the variation in $\mathrm{pH}$ due to change in sampling location was also insignificant (Table 1). The observed values, however, were well within the safe limit for drinking (WHO, 1973) as well as for crop production (FAO, 1975). Similar trend was also observed in case of conductivity. The values of conductivity ranged from 0.225 to 0.615 with an overall mean of $0.395 \mathrm{mmhos} / \mathrm{cm}$. Table 1 shows the mean seasonal values of conductivity in the range of 0.330 to $0.460 \mathrm{mmhos} / \mathrm{cm}$ and the mean locationwise values within 0.376 to $0.407 \mathrm{mmhos} / \mathrm{cm}$.

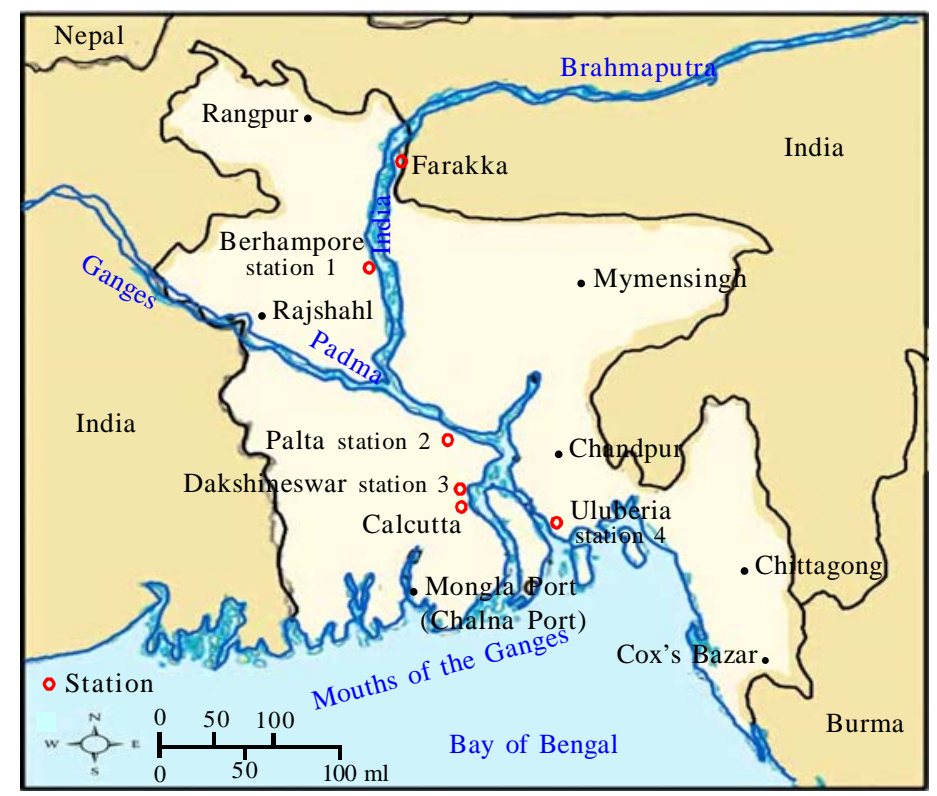

Fig. 1: Locations of the monitoring stations on river Ganga (BhagirathiHooghly stretch) in West Bengal 
Regarding the highest conductivity at Uluberia, the downstream station may be due to the inundation of sea water from Bay of Bengal during the tidal time (Gupta and Gupta, 1999). The lowest conductivity in monsoon may be due to the dilution effect of rain water. However, the locationwise change in conductivity was statistically insignificant. All the 96 surface water samples of the river Ganga were analyzed for $\mathrm{Fe}, \mathrm{Mn}$, $\mathrm{Zn}, \mathrm{Cu}, \mathrm{Cd}, \mathrm{Cr}, \mathrm{Pb}$ and $\mathrm{Ni}$. The presence of four essential micronutrients viz. Fe, $\mathrm{Mn}, \mathrm{Zn}$ and $\mathrm{Cu}$ was detected in 95, 93, 95 and 36 samples with concentrations within the ranges of $0.025-5.490,0.025-2.720,0.012-0.370,0.003-$ $0.032 \mathrm{mg} / \mathrm{L}$ with an overall mean of 1.052, 0.266, 0.716 and $0.005 \mathrm{mg} / \mathrm{L}$, respectively (Table 2). Besides, the presence of four toxic heavy metals viz. $\mathrm{Pb}, \mathrm{Cd}, \mathrm{Cr}$ and Ni were detected in 93, 20, 93 and 93 samples in the range of $0.001-0.250,0.001-0.003,0.001-0.044$ and $0.012-$ $0.375 \mathrm{mg} / \mathrm{L}$ with an overall mean of $0.140,0.002,0.170$ and $0.450 \mathrm{mg} / \mathrm{L}$, respectively. The seasonal average concentrations of various heavy metals viz. Fe, Mn, $\mathrm{Zn}, \mathrm{Cu}, \mathrm{Pb}, \mathrm{Cd}, \mathrm{Cr}$ and $\mathrm{Ni}$ at four locations in the surface water of the river Ganga were observed in the range of $0.353-2.345,0.085-0.712,0.042-0.111,0.003-0.008,0.005-$ 0.097, 0.001-0.003, 0.010-0.022 and 0.035-0.084 mg/L, respectively (Table 2). Except for $\mathrm{Fe}$ and $\mathrm{Mn}$, the concentrations of other metals in the Ganga water were lower than the observed metal concentrations of the river Bhadra at Karnataka and of the river Purna (Shah, et al., 2005). The mean concentrations of the metals were observed in the order: $\mathrm{Fe}>\mathrm{Mn}>\mathrm{Ni}>\mathrm{Cr}>\mathrm{Pb}>$ $\mathrm{Zn}>\mathrm{Cu}>\mathrm{Cd}$. Similar result was also observed by Khan, et al., (1998) in Ganga-Brahamputra-Meghna Estuary. The mean concentrations of Fe, $\mathrm{Mn}, \mathrm{Zn}, \mathrm{Cu}$, $\mathrm{Cd}, \mathrm{Cr}, \mathrm{Ni}$ and $\mathrm{Pb}$ in the surface water at four locations varied from $0.586-1.485,0.150-0.420,0.055-0.085,0.004-$ 0.006, 0.001-0.002, 0.016-0.018, 0.034-0.054 and 0.008$0.024 \mathrm{mg} / \mathrm{L}$ (Table III). Out of these four experimental stations, the highest mean concentrations of $\mathrm{Fe}$ $(1.485 \mathrm{mg} / \mathrm{L}), \mathrm{Zn}(0.085 \mathrm{mg} / \mathrm{L})$ and $\mathrm{Cu}(0.006 \mathrm{mg} / \mathrm{L})$ were observed at Palta where as $\mathrm{Mn}(0.42 \mathrm{mg} / \mathrm{L})$ and $\mathrm{Ni}$ $(0.054 \mathrm{mg} / \mathrm{L})$ were maximum at Berhampore and $\mathrm{Cr}$ $(0.018 \mathrm{mg} / \mathrm{L})$ at both Dakshineswar and Uluberia and $\mathrm{Pb}(0.024 \mathrm{mg} / \mathrm{L})$ at Uluberia. The highest concentrations of most of the heavy metals (Fe, $\mathrm{Zn}$ and $\mathrm{Cu}$ ) at Palta may be due to the discharge of heavy metal loaded industrial waste water (Shah, et al., 2005). The spatial changes in the concentrations of $\mathrm{Zn}, \mathrm{Cu}, \mathrm{Cr}, \mathrm{Ni}$ and $\mathrm{Pb}$, however, were not statistically significant. Throughout the year, the mean concentrations of $\mathrm{Fe}, \mathrm{Mn}, \mathrm{Zn}, \mathrm{Cu}$, $\mathrm{Cd}, \mathrm{Cr}, \mathrm{Ni}$ and $\mathrm{Pb}$ in the surface water of the river Ganga in three different seasons varied from $0.76-1.52,0.132$ 0.423, 0.063-0.084, 0.005-0.006, 0.001-0.003, 0.014-0.020, $0.030-0.060$ and $0.007-0.020 \mathrm{mg} / \mathrm{L}$, respectively (Figs. 2 and 3). Similar trends of results were also observed by Haque, et al., (2005) in the surface water of the river Ganga at Sundarban estuary. The highest concentrations of $\mathrm{Cu}, \mathrm{Cd}, \mathrm{Cr}, \mathrm{Ni}$ and $\mathrm{Pb}$ (Fig. 2) were observed in winter, while those of $\mathrm{Mn}$ and $\mathrm{Zn}$ were observed in monsoon (Fig. 3) which may be due to a sudden rainfall followed by high river discharge from upstream environment (Khan, et al., 1998). But the maximum for Fe was observed in summer (Fig. 3). Among the eight heavy metals, significant seasonal change was noted in the concentrations of Fe, Mn, Cd and Cr, whereas in case of $\mathrm{Zn}, \mathrm{Cu}, \mathrm{Ni}$ and $\mathrm{Pb}$, the seasonal change was not significant. The correlation among the physico-chemical properties ( $\mathrm{pH}$ and conductivity) of water and different heavy metal concentrations were also studied and the results are presented in Table 4. There was no significant correlation observed in the changes of heavy metal concentrations with the $\mathrm{pH}$ of water. But Cd and Cr exhibited a significant positive correlation with conductivity, while Mn indicated a negative correlation with conductivity (Table 4).

Table 1: Changes in $\mathrm{pH}$ and conductance of surface water of the river Ganga in west Bengal

\begin{tabular}{|c|c|c|c|c|c|c|c|}
\hline \multirow{2}{*}{ Parameters } & \multirow{2}{*}{ Season } & \multicolumn{4}{|c|}{ Mean value of the parameters } & \multirow{2}{*}{ Average } & \\
\hline & & $\mathrm{BH}$ & PA & DK & $\mathrm{UL}$ & & \\
\hline \multirow{5}{*}{$\mathrm{pH}$} & Summer & 7.83 & 7.91 & 7.85 & 7.93 & 7.88 & \multirow{5}{*}{$\begin{aligned} \mathrm{SEM} & =0.039 \\
\mathrm{CD} & =0.110\end{aligned}$} \\
\hline & Monsoon & 7.63 & 7.72 & 7.71 & 7.59 & 7.66 & \\
\hline & Winter & 7.97 & 7.75 & 7.90 & 7.84 & 7.87 & \\
\hline & Average & 7.80 & 7.79 & 7.80 & 7.79 & 7.80 & \\
\hline & \multicolumn{6}{|c|}{$\mathrm{SEM}=0.045 ; \mathrm{CD}=0.127$} & \\
\hline \multirow{5}{*}{$\begin{array}{c}\mathrm{EC} \\
(\mathrm{mmhos} / \mathrm{cm})\end{array}$} & Summer & 0.382 & 0.394 & 0.401 & 0.426 & 0.401 & \multirow{5}{*}{$\begin{array}{c}\mathrm{SEM}=0.014 \\
\mathrm{CD}=0.039\end{array}$} \\
\hline & Monsoon & 0.313 & 0.341 & 0.338 & 0.319 & 0.330 & \\
\hline & Winter & 0.431 & 0.457 & 0.467 & 0.477 & 0.460 & \\
\hline & Average & 0.376 & 0.398 & 0.402 & 0.407 & 0.395 & \\
\hline & \multicolumn{6}{|c|}{$\mathrm{SEM}=0.017 ; \mathrm{CD}=0.048$} & \\
\hline
\end{tabular}


Table 2: Average concentrations of heavy metals in surface water of the river Ganga

\begin{tabular}{|c|c|c|c|c|c|}
\hline \multirow[t]{2}{*}{ Metal } & \multirow[t]{2}{*}{ Season } & \multicolumn{4}{|c|}{$\begin{array}{l}\text { Average joncentration of metals } \\
(\mathrm{mg} / \mathrm{L}) \text { at }\end{array}$} \\
\hline & & $\mathrm{BH}$ & PA & DK & UL \\
\hline \multirow{3}{*}{$\mathrm{Fe}$} & Winter & 0.651 & 1.234 & 0.792 & 0.353 \\
\hline & Summer & 1.744 & 2.345 & 1.413 & 1.584 \\
\hline & Monsoon & 0.365 & 0.884 & 1.120 & 1.155 \\
\hline \multirow{3}{*}{$\mathrm{Mn}$} & Winter & 0.181 & 0.123 & 0.085 & 0.152 \\
\hline & Summer & 0.369 & 0.251 & 0.177 & 0.172 \\
\hline & Monsoon & 0.712 & 0.417 & 0.436 & 0.139 \\
\hline \multirow{3}{*}{$\mathrm{Zn}$} & Winter & 0.085 & 0.068 & 0.042 & 0.084 \\
\hline & Summer & 0.065 & 0.084 & 0.053 & 0.082 \\
\hline & Monsoon & 0.095 & 0.111 & 0.083 & 0.058 \\
\hline \multirow{3}{*}{$\mathrm{Cu}$} & Winter & 0.007 & 0.006 & 0.007 & 0.004 \\
\hline & Summer & 0.003 & 0.004 & 0.008 & 0.006 \\
\hline & Monsoon & 0.004 & 0.007 & 0.004 & 0.003 \\
\hline \multirow{3}{*}{$\mathrm{Cd}$} & Winter & 0.002 & 0.003 & 0.002 & 0.003 \\
\hline & Summer & 0.001 & 0.001 & 0.003 & 0.002 \\
\hline & Monsoon & 0.001 & ND & ND & ND \\
\hline \multirow{3}{*}{$\mathrm{Ni}$} & Winter & 0.084 & 0.042 & 0.035 & 0.083 \\
\hline & Summer & 0.041 & 0.035 & 0.044 & 0.034 \\
\hline & Monsoon & 0.045 & 0.053 & 0.038 & 0.035 \\
\hline \multirow{3}{*}{$\mathrm{Pb}$} & Winter & 0.021 & 0.005 & 0.005 & 0.052 \\
\hline & Summer & 0.008 & 0.006 & 0.097 & 0.003 \\
\hline & Monsoon & 0.014 & 0.015 & 0.009 & 0.017 \\
\hline \multirow{3}{*}{$\mathrm{Cr}$} & Winter & 0.018 & 0.021 & 0.022 & 0.024 \\
\hline & Summer & 0.010 & 0.013 & 0.017 & 0.018 \\
\hline & Monsoon & 0.017 & 0.014 & 0.016 & 0.013 \\
\hline
\end{tabular}

ND: not detected

Table 3: Spatial changes in heavy metal content in the surface water of the river Ganga

\begin{tabular}{ccccccccc}
\hline \multirow{2}{*}{ Locations } & \multicolumn{6}{c}{ Heavy metal concentration in water $(\mathrm{mg} / \mathrm{L})$} \\
& $\mathrm{Fe}$ & $\mathrm{Mn}$ & $\mathrm{Zn}$ & $\mathrm{Cu}$ & $\mathrm{Cd}$ & $\mathrm{Cr}$ & $\mathrm{Ni}$ & $\mathrm{Pb}$ \\
\hline $\mathrm{BH}$ & 0.586 & 0.420 & 0.075 & 0.005 & 0.001 & 0.016 & 0.054 & 0.014 \\
PA & 1.485 & 0.260 & 0.085 & 0.006 & 0.001 & 0.017 & 0.041 & 0.009 \\
DK & 1.110 & 0.023 & 0.055 & 0.006 & 0.002 & 0.018 & 0.034 & 0.008 \\
UL & 1.030 & 0.150 & 0.071 & 0.004 & 0.002 & 0.018 & 0.049 & 0.024 \\
SEM & 0.231 & 0.081 & 0.014 & 0.002 & 0.000 & 0.002 & 0.011 & 0.006 \\
CD & 0.651 & 0.228 & 0.039 & 0.006 & 0.000 & 0.006 & 0.031 & 0.017 \\
\hline
\end{tabular}

Table 4: Correlation of different heavy metals, $\mathrm{pH}$ and EC of the surface water of the river Ganga

\begin{tabular}{lllllllllll}
\hline & $\mathrm{pH}$ & $\mathrm{EC}$ & $\mathrm{Fe}$ & $\mathrm{Mn}$ & $\mathrm{Zn}$ & $\mathrm{Cu}$ & $\mathrm{Cd}$ & $\mathrm{Cr}$ & $\mathrm{Ni}$ & $\mathrm{Pb}$ \\
\hline $\mathrm{pH}$ & 1.00 & & & & & & & & & \\
$\mathrm{EC}$ & 0.18 & 1.00 & & & & & & & & \\
$\mathrm{Fe}$ & -0.06 & -0.11 & 1.00 & & & & & & & \\
$\mathrm{Mn}$ & -0.19 & $-0.30^{*}$ & 0.01 & 1.00 & & & & & & \\
$\mathrm{Zn}$ & -0.01 & 0.01 & -0.15 & 0.09 & 1.00 & & & & & \\
$\mathrm{Cu}$ & -0.13 & -0.02 & 0.05 & -0.02 & 0.09 & 1.00 & & & & \\
$\mathrm{Cd}$ & 0.16 & $0.43^{*}$ & -0.07 & -0.17 & -0.01 & 0.18 & 1.00 & & & \\
$\mathrm{Cr}$ & 0.09 & $0.34^{*}$ & $-0.23^{*}$ & -0.04 & 0.13 & 0.01 & 0.25 & 1.00 & & \\
$\mathrm{Ni}$ & 0.01 & -0.06 & -0.08 & $0.26^{*}$ & $0.29^{*}$ & -0.07 & -0.06 & 0.17 & 1.00 & \\
$\mathrm{~Pb}$ & 0.06 & 0.04 & -0.12 & 0.07 & -0.05 & 0.07 & -0.1 & 0.12 & 0.12 & 1.00 \\
\hline Indicates correlation is significant at the 0.05 level (2-tailed) & &
\end{tabular}

Among the heavy metals themselves, a significant negative correlation was observed between $\mathrm{Fe}$ and $\mathrm{Cr}$, whereas Ni exhibited a significant positive correlation with $\mathrm{Mn}$ and $\mathrm{Zn}$. This will help to understand the nature of these metals and their species speciation in the aquatic environment.

The concentrations of $\mathrm{Zn}, \mathrm{Cu}, \mathrm{Cd}$ and $\mathrm{Cr}$ were within the safe limit for both drinking as well as for crop production but the concentrations of $\mathrm{Fe}, \mathrm{Mn}, \mathrm{Pb}$ and $\mathrm{Ni}$ exceeded the BIS, (1991) standard for drinking (0.3 mg/L for Fe, $0.1 \mathrm{mg} / \mathrm{L}$ for $\mathrm{Mn}, 0.05 \mathrm{mg} / \mathrm{L}$ for $\mathrm{Cu}$ and $\mathrm{Pb}, 0.01 \mathrm{mg} / \mathrm{L}$ for $\mathrm{Cd}$ ) in 79, 67, 24 and $84 \%$ of the analyzed samples, respectively (Fig. 4). Whereas, only the concentration of Mn exceeded the safe limit for crop production $(5.0 \mathrm{mg} / \mathrm{L}$ for $\mathrm{Fe}, 0.2 \mathrm{mg} / \mathrm{L}$ for $\mathrm{Mn}$, $0.2 \mathrm{mg} / \mathrm{L}$ for $\mathrm{Cu}, 5.0 \mathrm{mg} / \mathrm{L}$ for $\mathrm{Pb}$ and $0.01 \mathrm{mg} / \mathrm{L}$ for $\mathrm{Cd}$; FAO, 1975) in $29 \%$ of the total samples (Fig. 4).

The river water exhibited a slightly alkaline $\mathrm{pH}$ and the conductivity apparently increased along the downstream due to the tidal effect of Bay of Bengal. The observed $\mathrm{pH}$ of the river water was well within the safe limit for drinking (WHO, 1973) as well as for crop production (FAO, 1975). Although conductivity increased towards the downstream of the river attributable to the tidal effect of Bay of Bengal (Gupta and Gupta, 1999) the change was not significant. The lowest conductivity in monsoon may be due to the dilution effect of rain water. The relative dominance of the heavy metals in water was observed in the following sequence: $\mathrm{Fe}>\mathrm{Mn}>\mathrm{Ni}>\mathrm{Cr}>\mathrm{Pb}>\mathrm{Zn}>\mathrm{Cu}$ $>\mathrm{Cd}$. The highest concentrations of most of the heavy metals (Fe, $\mathrm{Zn}$ and $\mathrm{Cu}$ ) at Palta may be due to the discharge of heavy metal loaded industrial waste water (Shah, et al., 2005). There was no significant correlation observed in the changes of heavy metal concentrations with the $\mathrm{pH}$ of water. But $\mathrm{Cd}$ and $\mathrm{Cr}$ exhibited a significant positive correlation with conductivity, while $\mathrm{Mn}$ indicated a negative correlation with conductivity. Considering the status of heavy metal concentrations in water, it may be concluded that the river water as such is not suitable for drinking purpose due to the excess concentrations of $\mathrm{Fe}, \mathrm{Mn}, \mathrm{Pb}$ and $\mathrm{Ni}$ and it may not be suitable for irrigation due to the excess concentration of Mn. The excess heavy metal load of river water can be attributed to the discharge of industrial effluents and municipal wastes, geology of river bed and catchment area. Though some of the detected heavy metals are beneficial for human and 


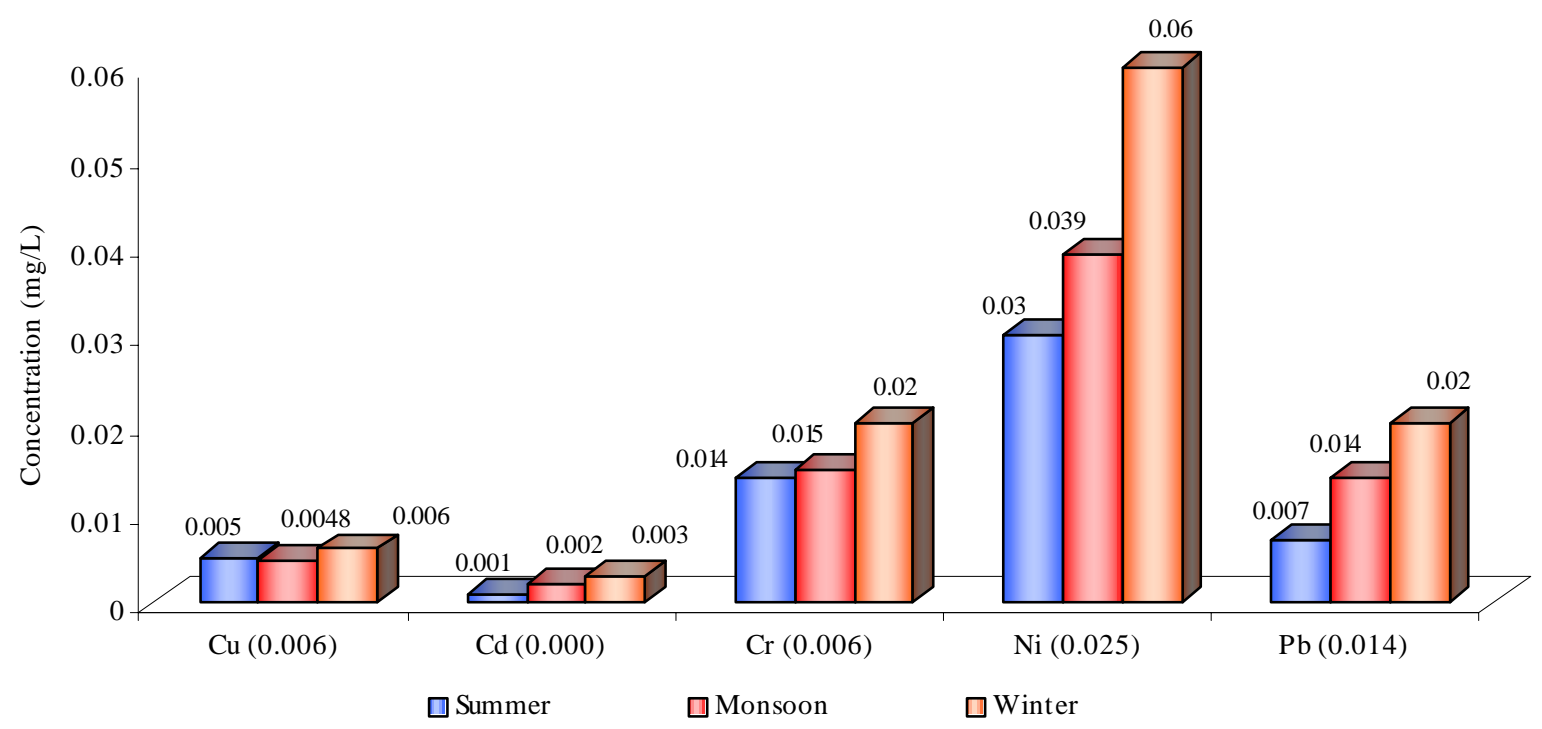

Fig. 2: Seasonal variation in the concentrations of $\mathrm{Cu}, \mathrm{Cd}, \mathrm{Cr}, \mathrm{Ni}$ and $\mathrm{Pb}$ (values in the parentheses indicate the corresponding CD value)

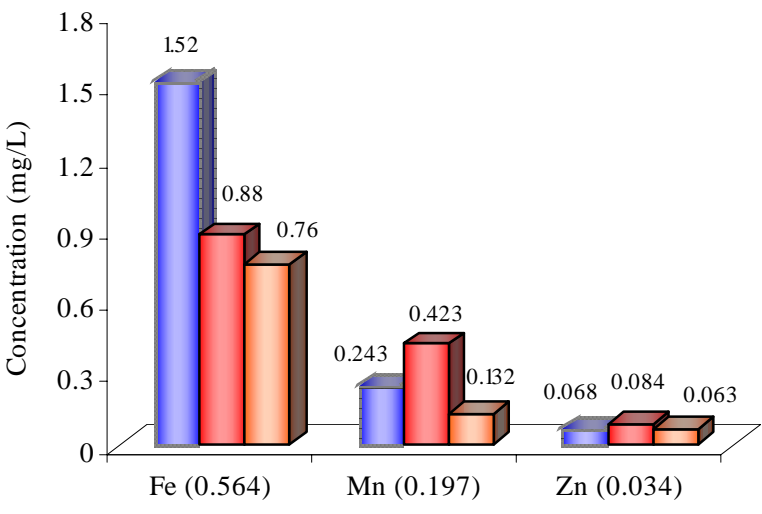

口 Summer

$\square$ Monsoon

Fig. 3: Seasonal variation in the concentrations of $\mathrm{Fe}, \mathrm{Mn}$ and $\mathrm{Zn}$ (values in the parentheses indicate the corresponding $\mathrm{CD}$ value)

plants up to a certain limit, it may be harmful beyond that. Adoption of adequate measures to remove the heavy metal load from the industrial waste water and renovation of sewage treatment plants are suggested to avoid further deterioration of the river water quality.

\section{ACKNOWLEDGEMENTS}

The authors would like to thank the National River Conservation Directorate, Ministry of Environment and Forests, Goverment of India for the financial assistance. Infrastructural facility provided by BCKV is duly acknowledged.

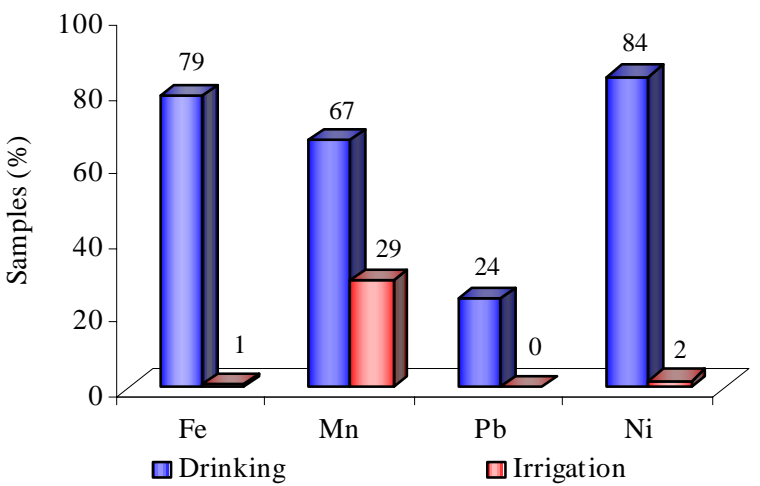

Fig. 4: Percentage of samples not suitable for drinking and crop production

\section{REFERENCES}

Abbasi, S. A.; Abbasi, N.; Soni, R., (1998). Heavy metal in the

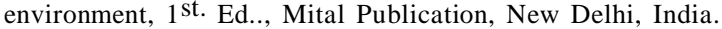
Amman, A. A.; Michalke, B.; Schramel, P., (2002). Speciation of heavy metals in environmental water by ion chromatography coupled to ICP-MS. Anal. Biochem., 372, 448-452.

APHA (1995). Standard methods for the examination of water and waste water, $19^{\text {th. }}$ Ed, American Public Health Association, American Water Works Association \& Water Environment Federation, Washington, DC.

BIS (1991). Indian standards drinking water specification, Bureau of Indian Standard, Indian Standard 10500.

Bruins, M. R.; Kapil, S.; Oehme, F. W., (2000). Microbial resistance to metals in the environment. Ecotox. Environ. Safe. 45, 198-207. 
Das, R. K.; Bhowmick, S.; Ghosh, S. P.; Dutta, S., (1997). Coliform and fecal coliform bacterial load in a stretch of Hooghly, in K. K Vass and M. Sinha, (Eds.), Proceedings of the National seminar on changing perspectives of inland fisheries, Inland Fisheries Society of India, Barrackpore.

FAO (1975). Manual of methods in aquatic environment research, Food and Agricultural Organization of the United Nations, Part 1: Methods of detection, measurement and monitoring of water pollution.

Ghosh, S.; Vass, K. K., (1997). Role of sewage treatment plant in Environmental mitigation. K. K. Vass and M. Sinha (Eds.), Proceedings of the national seminar on changing perspectives of inland fisheries, Inland Fisheries Society of India, Barrackpore, 36-40.

Gupta, B. K.; Gupta, R. R., (1999). Physico-chemical and biological study of drinking water in Satna, Madhya Pradesh., Pollut. Res., 18, 523-525.

Haque, M. R.; Ahmad, J. U.; Chowdhury, M. D. A.; Ahmed, M. K.; Rahman, M. S., (2005). Seasonal variation of heavy metal concentrations in surface water of the rivers and estuaries of Sundarban mangrove forest, Pollut. Res., 24, 463-472.

ISI (1982). Indian standard tolerance limits for inland surface water subject to pollution, $2^{\text {nd. }}$ revision, Indian Standard Institute. 2296.

Jain, V. K., (1978). Studies on effect of cadmium on the growth pattern of phaseolus aurius varieties, Absi, I. Bot. Conf. JIBS.,57-84.
John, D. Hem., (1991). Study and interpretation of the chemical characteristics of natural water, Scientific Publishers, Jodhpur, India.

Johnson, F. M., (1998). The genetic effects of environmental lead., Mutat. Res., 410, 123-140.

Khan, Y. S. A.; Hussain, M. S.; Hossain, S. M. G.; Hallimuzzaman, A. H. M., (1998). An environmental assessment of trace metals in Ganges-Brahamputra-Meghna Estuary., J. Rem. Sens. Environ., 2, 103-117.

Lantzy, R. J.; Mackenzie, F. T., (1979). Atmospheric trace metals: global cycles and assessment of man's impact, Geochim. Cosmochim. Acta., 43, 511- 525.

Marschner, H., (1995). Mineral nutrition of higher plants, Academic Press, London.

Nriagu, J. O., (1979). Global inventory of natural and anthropogenic emissions of trace metals to the atmosphere, Nature, 279, 409-411.

Ross, S. M., (1994). Toxic metals in soil-plant systems, Wiley, Chichester, U. K.

Shah, B. A.; Shah, A. V.; Ahire, N. D., (2005). Characteristics of Purna river water of Navasari and removal of trace toxic metals by ion-exchange process using preconcentration techniques, Pollut. Res., 24, 415-422.

Tsuji, L. J. S.; Karagatzides, J. D., (2001). Chronic lead exposure, body condition and testis mass in wild Mallard Ducks, B. Environ. Contam. Tox., 67, 489-495.

WHO (1973). World Health Organization technical report series No. 532, Geneva.

\section{AUTHOR (S) BIOSKETCHES}

Kar, D., M.Sc., Ph.D. Research student, Department of Agricultural Chemistry \& Soil Science, Faculty of Agriculture, Bidhan Chandra Krishi Viswavidyalaya, Kalyani-741235, West Bengal, India.

Email: dipankarkar@gmail.com

Sur, P., M.Sc., Ph.D. Rresearch student, Department of Agricultural Chemistry \& Soil Science, Faculty of Agriculture, Bidhan Chandra Krishi Viswavidyalaya, Kalyani-741235, West Bengal, India.

Email:pintu_soil@yahoo.com

Mandal, S. K., M.Sc., Ph.D. Research associate, Department of Agricultural Chemistry \& Soil Science, Faculty of Agriculture, Bidhan Chandra Krishi Viswavidyalaya, Kalyani-741235, West Bengal, India.

Email: santanukumarmandal@rediffmail.com

Saha, T., M.Sc., Ph.D. Research associate, Department of Agricultural Chemicals, Faculty of Agriculture, Bidhan Chandra Krishi Viswavidyalaya, Kalyani-741235, West Bengal, India. Email: t.saha@rediffmail.com

Kole, R. K., M.Sc., Ph.D. Reader, Department of Agricultural Chemicals, Faculty of Agriculture, Bidhan Chandra Krishi Viswavidyalaya, Kalyani-741235, West Bengal, India. Email: rkkole@yahoo.com

This article should be referenced as follows:

Kar, D.; Sur, P.; Mandal, S. K.; Saha, T.; Kole, R. K., (2008). Assessment of heavy metal pollution in surface water. Int. J. Environ. Sci. Tech., 5 (1), 119-124. 